\title{
Synthesis and evaluation of some new oxazolones and imidazolones as antioxidant additives for Egyptian lubricating oils
}

\author{
Ahmed El-Mekabaty*, Osman M. O. Habib, Hussein M. Hassan and Evelin B. \\ Moawad
}

Department of Chemistry, Faculty of Science, Mansoura University, Mansoura 35516, Egypt

(C) China University of Petroleum (Beijing) and Springer-Verlag Berlin Heidelberg 2012

\begin{abstract}
Oxazolone derivative 2 was utilized as a key intermediate for synthesis of some new oxazolone and imidazolone derivatives. Reaction of oxazolone derivative $\mathbf{2}$ with diamines under different conditions afforded the corresponding imidazolone derivatives 3-8, respectively. Moreover, oxazolone 2 reacted with some heterocyclic amines in glacial acetic acid giving the corresponding imidazolone derivatives 9-14, respectively. Cyclocondensation of thiosemicarbazide with compound $\mathbf{2}$ in dry pyridine afforded compound 15. Addition of secondary amines to olefin double bond of compound $\mathbf{2}$ gave the corresponding addition products 16-19, respectively. Michael addition of compound 2 with some active methylene compounds afforded oxazolone derivatives 20-23, respectively. These prepared products were evaluated as antioxidant and corrosion inhibitors for gasoline lubricating oil and compounds $\mathbf{6 a - c}, \mathbf{1 0}$ and 15 exhibited the highest antioxidant and anticorrosive activities. The effect of concentration of additives was studied to recommend the optimum concentration to be used. The results showed, for additive $\mathbf{1 5}$, $0.1 \mathrm{~g}$ for $1 \mathrm{~L}$ oil was the more effective concentration. Measurements for thermal analysis and of surface tension of oil after oxidation were also carried out.
\end{abstract}

Key words: Oxazolone, imidazolone, benzoimidazole, surface tension, thermal stability, antioxidant additives.

\section{Introduction}

Lubricating oils produced by solvent refining of high boiling petroleum distillates consist mainly of long chain hydrocarbon molecules. In internal combustion engines, lubricating oils suffer from autoxidation as a result of contact at elevated temperatures with air for a long period and with metals, from which the engine was made.

These metals act as catalysts for oxidation of lubricating oil and are responsible for the formation of oxygenated oilsoluble and insoluble products which exert an adverse effect on the performance of the lubricating oils (Hassan et al, 1985; 2000; Hassan, 1998; Façanha et al, 2007; Aucelio et al, 2007; Suzuki et al, 2009). With increasing demands being placed on lubricants for automotive engines and transmissions and high-speed machinery, much research has been devoted to the development of improved lubricants. Not only petroleumbased lubricants, but also synthetic lubricants require additives to improve their lubricating and aging properties when exposed to many severe end use conditions, e.g., for extreme pressure applications where metal to metal contact

\footnotetext{
* Corresponding author. email: a_el_m11@yahoo.com
}

Received November 15, 2011 may be encountered, additives must be used to form low shear strength surface films to minimize wear. Other additives inhibit oxidation; prevent rusting and improve the viscosity index and pour points of the lubricants.

\section{Experimental section}

\subsection{Synthesis}

The melting points (uncorrected) of all the compounds were determined on Gallenkamp electric melting point apparatus, and Fourier transform Infrared Spectroscopy (FTIR) ( $\mathrm{KBr}$ disk) was performed on a Mattson 5000 FTIR spectrometer which has spectral resolution of $4 \mathrm{~cm}^{-1}$ and scan number of 64 in the spectral range $400-4000 \mathrm{~cm}^{-1}$ using the Win first program. Calibration of the frequency reading was carried out using polystyrene film at the Microanalytical unit, Faculty of Science, Mansoura University, Mansoura, Egypt. ${ }^{1}$ H-NMR spectra, were determined on a Brucker WPSY 300 MHZ spectrometer with TMS as internal standard and the chemical shifts are in $\sigma \mathrm{ppm}$. Mass spectra were recorded at $70 \mathrm{ev}$ with a Varian MAT 311. Elemental analysis was satisfactory for all the synthesized compounds $\mathbf{2 - 2 3}$, and elemental analysis was carried out in the Faculty of Science, Cairo University, Egypt. (Z)-4-((5-Oxo-2-phenyloxazol- 
4(5H)-ylidene)methyl)phenyl-4-methylbenzene sulfonate (2) was prepared according to the previously reported method (Girges et al, 1989).

\subsubsection{Reaction of oxazolone (2) with $o$-phenylenediamine a) By fusion at $140{ }^{\circ} \mathrm{C}$ and at $190{ }^{\circ} \mathrm{C}$}

A mixture of oxazolone $2(0.003 \mathrm{~mol}), o$-phenylenediamine $(0.003 \mathrm{~mol})$ and freshly fused sodium acetate $(0.2 \mathrm{gm})$ was fused at $140{ }^{\circ} \mathrm{C}$ and $/$ or $190{ }^{\circ} \mathrm{C}$ for $3 \mathrm{~h}$. In each case, the reaction mixture was cooled, washed with dilute $\mathrm{HCl}$, and the separated solid product was dried and recrystallized from methanol to give compounds $\mathbf{3}$ and $\mathbf{4}$, respectively. Their characteristic spectral data are as follows:

4-(2-Benzamido-2-(1H-benzo[d]imidazol-2-yl)vinyl) phenyl4-methylbenzene sulfonate (3). IR (KBr), $v / \mathrm{cm}^{-1}: 1680$ (CO, amidic), 3174-3289 (2NH), $1360\left(\mathrm{SO}_{3}\right), 1600(\mathrm{C}=\mathrm{N})$, $1590(\mathrm{C}=\mathrm{C})$. EIMS (m/z, \%): $509\left(\mathrm{M}^{+}, 20\right), 422$ (54), 353 (23), 268 (11), 263 (16), 191 (32), 104 (100), 77 (37).

(Z)-4-((1-Phenyl-3H-benzo[d]imidazo[1,5-a]imidazol3-ylidene)methyl)phenyl-4-methyl benzenesulfonate (4). IR $(\mathrm{KBr}), \mathrm{v} / \mathrm{cm}^{-1}: 1360\left(\mathrm{SO}_{3}\right), 1620(\mathrm{C}=\mathrm{N})$. EIMS $(\mathrm{m} / \mathrm{z}, \%): 489$ $\left(\mathrm{M}^{+}-2,18\right), 341$ (38), 295 (25), 213 (40), 193 (48), 147 (73), 91 (38), 44 (100). ${ }^{1} \mathrm{H}$ NMR (DMSO) ( $\left.\delta, \mathrm{ppm}\right), 2.4$ (s, 3H, $\left.\mathrm{CH}_{3}\right), 7.1-8.2(\mathrm{~m}, 18 \mathrm{H}, \mathrm{Ar}-\mathrm{H}, \mathrm{CH}=\mathrm{C})$.

\section{b) By refluxing in ethyl alcohol}

A mixture of oxazolone $2(0.003 \mathrm{~mol})$ and $o$-phenylenediamine $(0.003 \mathrm{~mol})$ in absolute ethanol $(20 \mathrm{~mL})$ was refluxed for $6 \mathrm{~h}$. The solid product that separated on cooling was filtered off and recrystallized from ethanol to give compound $\mathbf{5}$.

(Z)-4-(3-((2-Aminophenyl)amino)-2-benzamido-3oxoprop-1-en-1-yl)phenyl-4-methyl benzenesulfonate (5). IR $(\mathrm{KBr}), \mathrm{v} / \mathrm{cm}^{-1}: 1680$ (CO, amidic), 3430, $3490(2 \mathrm{NH}), 3225-$ $3370\left(\mathrm{NH}_{2}\right), 1360\left(\mathrm{SO}_{3}\right), 1620(\mathrm{C}=\mathrm{N})$. EIMS (m/z, \%): 527 $\left(\mathrm{M}^{+}, 30\right), 495$ (11), 480 (14), 422 (27), 380 (56), 268 (16), 253 (100), 105 (52). ${ }^{1} \mathrm{H}$ NMR (DMSO) ( $\left.\delta, \mathrm{ppm}\right), 2.4\left(\mathrm{~s}, 3 \mathrm{H}, \mathrm{CH}_{3}\right)$, 4.5 (br, $2 \mathrm{H}, \mathrm{NH}_{2}$ ), 6.9-8.3 (m, 20H, $\left.\mathrm{Ar}-\mathrm{H}, \mathrm{CH}=\mathrm{C}, 2 \mathrm{NHCO}\right)$.

\section{c) By refluxing in glacial acetic acid}

A mixture of oxazolone $2(0.003 \mathrm{~mol})$ and $o$-phenylenediamine $(0.003 \mathrm{~mol})$ in glacial acetic acid $(20 \mathrm{~mL})$ containing freshly fused sodium acetate $(0.2 \mathrm{gm})$ was heated under reflux for $7 \mathrm{~h}$. The reaction mixture was left to cool, and then poured over ice. The solid that separated was filtered off, dried and recrystallized from ethanol-ether was compound 6 .

(Z) - 4 - ( ( 1 - ( 2 - A c e ta midopheny 1$)$ - 5 - ox o- 2 phenyl-1H-imidazol-4(5H)-ylidene) methyl)phenyl 4-methylbenzenesulfonate (6). IR (KBr), $v / \mathrm{cm}^{-1}: 1698(\mathrm{CO}$, amidic), $1665(\mathrm{CONH}), 3133(\mathrm{NH}), 1360\left(\mathrm{SO}_{3}\right), 1610(\mathrm{C}=\mathrm{N})$. EIMS (m/z, \%): $551\left(\mathrm{M}^{+}, 45\right), 451$ (42), 368 (25), $282(26)$, 197 (19), 148 (40), 78 (51), 63 (100). ${ }^{1} \mathrm{H}$ NMR (DMSO) $(\delta$, ppm), $2.4\left(\mathrm{~s}, 3 \mathrm{H}, \mathrm{CH}_{3}\right), 2.2\left(\mathrm{~s}, 3 \mathrm{H}, \mathrm{CH}^{3} \mathrm{CO}\right), 7.1-8.2(\mathrm{~m}, 19 \mathrm{H}$, $\mathrm{Ar}-\mathrm{H}, \mathrm{CH}=\mathrm{C}, \mathrm{NH}$ ).

\subsubsection{Reaction of oxazolone (2) with $p$-phenylenediamine}

A mixture of oxazolone $2(0.003 \mathrm{~mol})$ and $p$-phenylenediamine $(0.003 \mathrm{~mol})$ in glacial acetic acid $(30$ $\mathrm{mL})$ containing freshly fused sodium acetate $(0.2 \mathrm{gm})$ was heated under reflux for $5 \mathrm{~h}$. The reaction mixture was left to cool, and the solid that separated was filtered off, dried and recrystallized from acetic acid to give compound 7 .

(Z)-4-((1-(4-acetamidophenyl)-5-oxo-2-phenyl-1H-imid-
az-ol-4(5H)-ylidene) methyl)phenyl 4-methylbenzenesulfonate (7). IR (KBr), $v / \mathrm{cm}^{-1}: 1700$ (CO, amidic), $1660(\mathrm{CON})$, $3350(\mathrm{NH}), 1360\left(\mathrm{SO}_{3}\right), 1640(\mathrm{C}=\mathrm{N})$. EIMS (m/z, \%): 552 $\left(\mathrm{M}^{+}, 15\right), 446$ (12), 342 (15), 256 (25), 157 (16), 109 (35), 84 (63), 40 (100). ${ }^{1} \mathrm{H}$ NMR (DMSO) ( $\delta$, ppm), $2.4\left(\mathrm{~s}, 3 \mathrm{H}, \mathrm{CH}_{3}\right.$ ), 2.6 (s, $\left.3 \mathrm{H}, \mathrm{CH}_{3} \mathrm{CO}\right), 7.1-8.4(\mathrm{~m}, 19 \mathrm{H}, \mathrm{Ar}-\mathrm{H}, \mathrm{CH}=\mathrm{C}, \mathrm{NH})$.

A mixture of oxazolone $2(0.006 \mathrm{~mol})$ and $p$-phenylenediamine $(0.003 \mathrm{~mol})$ in glacial acetic acid $(30 \mathrm{~mL})$ containing freshly fused sodium acetate $(0.5 \mathrm{gm})$ was heated under reflux for $8 \mathrm{~h}$. The reaction mixture was left to cool, and then poured over ice, the solid that separated out was filtered off, dried and recrystallized from dimethylformamide giving bis imidazolone $\mathbf{8}$.

$\left(\left(1 \mathrm{Z}, 1^{\prime} \mathrm{Z}\right)-\left(1,1^{\prime}-(1,4-\right.\right.$ phenylene $)$ bis $(5-$ oxo-2-phenyl-1Himi-dazole-1(5H)-yl-4(5H)-ylidene))bis(methanylylidene))bis(4,1-phenylene)bis(4-methyl benzenesulfonate) (8). IR $(\mathrm{KBr}), \mathrm{v} / \mathrm{cm}^{-1}: 1675-1688(2 \mathrm{CON}), 1360\left(\mathrm{SO}_{3}\right), 1620(\mathrm{C}=\mathrm{N})$. EIMS (m/z, \%): $911\left(\mathrm{M}^{+}, 22\right), 788$ (33), 540 (11), 382 (100), 364 (44), 301 (8), 285 (53), 218 (17), 155 (25), 75 (33). ${ }^{1} \mathrm{H}$ NMR (DMSO) ( $\delta, \mathrm{ppm}), 2.4\left(\mathrm{br}, 6 \mathrm{H}, 2 \mathrm{CH}_{3}\right), 6.9-8.3(\mathrm{~m}, 32 \mathrm{H}$, $\mathrm{Ar}-\mathrm{H}, 2 \mathrm{CH}=\mathrm{C})$.

\subsubsection{Reaction of oxazolone (2) with heterocyclic amines}

A mixture of $2(0.01 \mathrm{~mol})$ and the appropriate heterocyclic amines namely 2 -aminopyridine, 3 -aminopyridine, 2-aminothiazole, 2-amino benzothiazole, 4-aminoantipyrine and 3-amino-4-(phenyldiazenyl)-1H-pyrazol-5(4H)-one (0.01 $\mathrm{mol})$ and freshly fused sodium acetate $(0.5 \mathrm{gm})$ in glacial acetic acid $(40 \mathrm{~mL})$ was refluxed for $5-8 \mathrm{~h}$, then cooled and the reaction mixture was poured into ice-water. The solids separated were filtered off and recrystallized from methanol to give imidazolone derivatives $\mathbf{9 - 1 4}$.

(Z)-4-((5-Oxo-2-phenyl-1-(pyridin-2-yl)-1H-imidazol4(5H)-ylidene)methyl) phenyl-4-methyl benzenesulfonate (9). IR (KBr), $v / \mathrm{cm}^{-1}: 1680\left(\mathrm{CO}\right.$, amidic), $1360\left(\mathrm{SO}_{3}\right), 1620(\mathrm{C}=\mathrm{N})$. EIMS (m/z, \%): $496\left(\mathrm{M}^{+}+1,16\right), 267$ (14), 232 (13), 195 (18), 153 (14), 101 (12), 86 (47), 74 (100).

(Z)-4-((5-Oxo-2-phenyl-1-(pyridin-3-yl)-1H-imidazol$4(5 \mathrm{H})$-ylidene)methyl) phenyl-4-methyl benzenesulfonate (10). IR (KBr), $v / \mathrm{cm}^{-1}: 1680$ (CO, amidic), $1360\left(\mathrm{SO}_{3}\right), 1620$ $(\mathrm{C}=\mathrm{N})$. EIMS (m/z, \%): $495\left(\mathrm{M}^{+}, 24\right), 378(23), 256(41), 202$ (37), 184 (12), $126(15), 88$ (43), 58 (100).

(Z)-4-((5-Oxo-2-phenyl-1-(thiazol-2-yl)-1H-imidazol4(5H)-ylidene)methyl) phenyl-4-methylbenzenesulfonate (11). IR (KBr), $v / \mathrm{cm}^{-1}: 1680$ (CO, amidic), $1360\left(\mathrm{SO}_{3}\right), 1620$ $(\mathrm{C}=\mathrm{N})$. EIMS (m/z, \%): $501\left(\mathrm{M}^{+}, 41\right), 445$ (38), 404 (48), 388 (71), 347 (41), 294 (66), 263 (33), 191 (11), 105 (81), 58 (100).

(Z)-4-((1-(Benzo[d]thiazol-2-yl)-5-oxo-2-phenyl1H-imidazol-4(5H)-ylidene) methyl)-phenyl-4-methyl benzenesulfonate (12). IR (KBr), $v / \mathrm{cm}-1: 1680$ (CO, amidic), 1360 (SO3), $1620(\mathrm{C}=\mathrm{N})$. EIMS (m/z, \%): $553(\mathrm{M}++2,20)$, 423 (20), 383 (41), 305 (59), 256 (25), 227 (48), 186 (11), $156(10), 122(15), 75(100)$.

(Z)-4-((1-(1,5-Dimethyl-3-oxo-2-phenyl-2,3-dihydro-1Hpyrazol-4-yl)-5-oxo-2-phenyl-1H-imidazol-4(5H)-ylidene)methyl)phenyl-4-methylbenzenesulfonate (13). IR (KBr), $v / \mathrm{cm}^{-1}: 1680(\mathrm{CO}$, amidic $), 1360\left(\mathrm{SO}_{3}\right), 1620(\mathrm{C}=\mathrm{N})$. EIMS (m/z, \%): 604 (M+ 32), 450 (13), 347 (26), 290 (11), 263 (16), 231 (39), 156 (62), 105 (100). 
4-((1Z)-(5-Oxo-1-(5-oxo-4-(phenyldiazenyl)-4,5-dihydro1H-pyrazol-3-yl)-2-phenyl-1H-imidazol-4(5H)-ylidene)methyl)phenyl-4-methylbenzenesulfonate (14). IR ( $\mathrm{KBr})$, v/ $\mathrm{cm}^{-1}: 1680$ (CO, amidic), $3320(\mathrm{NH}), 1360\left(\mathrm{SO}_{3}\right), 1620$ $(\mathrm{C}=\mathrm{N})$. EIMS (m/z, \%): $605\left(\mathrm{M}^{+}, 21\right), 495$ (16), 449 (12), 369 (23), 255 (12), 196 (16), 104 (73), 91 (100).

\subsubsection{Reaction of oxazolone (2) with thiosemicarbazide}

Thiosemicarbazide $(0.03 \mathrm{~mol})$ was added to a solution of compound $2(0.01 \mathrm{~mol})$ in $30 \mathrm{~mL}$ dry pyridine, and the reaction mixture was heated under reflux for $8 \mathrm{~h}$, left to cool and then poured into cold water with stirring. The solid product was filtered off, washed with water several times and recrystallized from dimethylformamide to give compound $\mathbf{1 5}$.

(Z)-4-((5-phenyl-2-thioxo-2H-imidazo[1,5-b][1,2,4]triazol-7(3H)-ylidene)methyl) phenyl 4-methylbenzenesulfonate (15). IR (KBr), v/ $\mathrm{cm}^{-1}$ : $1376(\mathrm{C}=\mathrm{S}), 3442(\mathrm{NH}), 1340$ $\left(\mathrm{SO}_{3}\right), 1640(\mathrm{C}=\mathrm{N})$. EIMS (m/z, \%): $475\left(\mathrm{M}^{+}, 42\right), 411(75)$, 320 (18), 275 (53), 167 (57), 139 (27), 91 (100), 50 (49). ${ }^{1} \mathrm{H}$ NMR (DMSO) $(\delta, \mathrm{ppm}), 2.4\left(\mathrm{~s}, 3 \mathrm{H}, \mathrm{CH}_{3}\right), 9.8(\mathrm{~s}, 1 \mathrm{H}, \mathrm{NH})$, 7.2-8.3 (m, 14H, Ar-H, CH=C).

\subsubsection{Reaction of oxazolone (2) with secondary amines and thiophenol}

A mixture of oxazolone $2(0.05 \mathrm{~mol})$ and the appropriate reagent namely piperidine, morpholine, piperazine, and thiophenol $(0.05 \mathrm{~mol})$ in dry benzene $(30 \mathrm{~mL})$ was heated at $60{ }^{\circ} \mathrm{C}$ with stirring for $3-5 \mathrm{~h}$. The reaction mixture was left to stand overnight at room temperature, then petroleum ether $\left(40-60{ }^{\circ} \mathrm{C}\right)$ was added and the precipitated solid products were filtered off and recrystallized from benzene-hexane (2:1) to give 16-19, respectively.

4-((5-Oxo-2-Phenyl-4,5-dihydrooxazol-4-yl)(piperidin-1yl)methyl)phenyl-4-methyl benzenesulfonate (16). IR ( $\mathrm{KBr})$, $v_{\max } / \mathrm{cm}^{-1}: 1770(\mathrm{CO}$, lactone $), 1644(\mathrm{C}=\mathrm{N}), 1360\left(\mathrm{SO}_{3}\right)$. EIMS (m/z, \%): $504\left(\mathrm{M}^{+}, 12\right), 478$ (7.1), 365 (58), 282 (10), 161 (14), 85 (100), 72 (28). ${ }^{1} \mathrm{H}$ NMR (DMSO) $(\delta, \mathrm{ppm}), 2.4$ (s, 3H, $\left.\mathrm{CH}_{3}\right), 2.46-2.47\left(\mathrm{t}, 4 \mathrm{H}, \mathrm{N}\left(\mathrm{CH}_{2}\right) 2\right), 1.48-1.49\left(\mathrm{~m}, 6 \mathrm{H}, 3 \mathrm{CH}_{2}\right.$ of piperidine), 4.51-4.52 (m, 2H, N-CH, CH of oxazolone), 6.9$8.1(\mathrm{~m}, 14 \mathrm{H}, \mathrm{Ar}-\mathrm{H}, \mathrm{CH}=\mathrm{C})$.

4-(Morpholino(5-oxo-2-phenyl-4,5-dihydrooxazol-4-yl)methyl)phenyl-4-methyl benzene sulfonate (17). IR (KBr), $v_{\max } / \mathrm{cm}^{-1}: 1780\left(\mathrm{CO}\right.$, lactone), $1640(\mathrm{C}=\mathrm{N}), 1360\left(\mathrm{SO}_{3}\right)$. EIMS (m/z, \%): $506\left(\mathrm{M}^{+}, 16\right), 420$ (16), 265 (19), 161 (100), 117 (45), 93 (46), 57 (18). ${ }^{1} \mathrm{H}$ NMR (DMSO) ( $\delta$, ppm), 2.4 (s, 3H, $\left.\mathrm{CH}_{3}\right)$, 2.67-2.68 (t, 4H, N( $\left.\left(\mathrm{CH}_{2}\right)_{2}\right), 3.58-3.59$ (t, 4H, O $\left.\left(\mathrm{CH}_{2}\right)_{2}\right)$, 4.51-4.52 (m, 2H, N-CH, CH of oxazolone), 6.9-8.1 (m, 14H, $\mathrm{Ar}-\mathrm{H}, \mathrm{CH}=\mathrm{C})$.

4-((5-Oxo-2-phenyl-4,5-dihydrooxazol-4-yl)(piperazin-1yl)methyl)phenyl-4-methylbenzenesulfonate (18). IR (KBr), $v_{\max } / \mathrm{cm}^{-1}: 1780(\mathrm{CO}$, lactone), $3423(\mathrm{NH}), 1638(\mathrm{C}=\mathrm{N}), 1360$ $\left(\mathrm{SO}_{3}\right)$. EIMS (m/z, \%): $505\left(\mathrm{M}^{+}, 22\right), 441$ (26), 395 (52), 315 (12), 277 (53), 200 (61), 148 (79), 105 (100), 48 (61). ${ }^{1} \mathrm{H}$ NMR (DMSO) $(\delta, \mathrm{ppm}), 2.4\left(\mathrm{~s}, 3 \mathrm{H}, \mathrm{CH}_{3}\right), 2.65-2.66(\mathrm{~m}, 8 \mathrm{H}$, $\left.\mathrm{N}\left(\mathrm{CH}_{2}\right)_{4}\right), 4.51-4.52(\mathrm{~m}, 2 \mathrm{H}, \mathrm{N}-\mathrm{CH}, \mathrm{CH}$ of oxazolone $), 6.9-8.1$ (m, 15H, Ar-H, $\mathrm{CH}=\mathrm{C}, \mathrm{NH})$.

4-((5-Oxo-2-phenyl-4,5-dihydrooxazol-4-yl)(phenylthio)methyl)phenyl-4-methyl benzene sulfonate (19). IR (KBr), $v_{\max } / \mathrm{cm}^{-1}: 1780\left(\mathrm{CO}\right.$, lactone), $1640(\mathrm{C}=\mathrm{N}), 1360\left(\mathrm{SO}_{3}\right)$. EIMS (m/z, \%): 529 (M , 25), 401 (19), 316 (47), 257 (29), 213 (37), 188 (15), 101 (12), 77 (20), 43 (100).

\subsubsection{Reaction of oxazolone (2) with active methylene compounds}

A mixture of oxazolone $2(0.03 \mathrm{~mol})$, ethylcyanoacetate $(0.05 \mathrm{~mol})$ and few drops of piperidine in dry chloroform $(50 \mathrm{~mL})$ was heated under reflux for 8 hours. The solvent was evaporated under reduced pressure. The obtained solid product was filtered off and recrystallized from methanol to obtain 20.

ethyl2-cyano-3-(5-oxo-2-phenyl-4,5-dihydrooxazol-4-yl)3-(4-(tosyl-oxy)phenyl) propanoate (20). IR ( $\mathrm{KBr}), v_{\max } / \mathrm{cm}^{-1}$ : 1780 (CO, lactone), 1730 (CO, ester), $2110(\mathrm{CN}), 1640(\mathrm{C}=\mathrm{N})$, $1360\left(\mathrm{SO}_{3}\right)$. EIMS (m/z, \%): $533\left(\mathrm{M}^{+}, 10\right), 413$ (19), 341 (42), 304 (25), 280 (14), 189 (17), 168 (42), 105 (44), 77 (59), 43 (100). ${ }^{1} \mathrm{H}$ NMR (DMSO) $(\delta, \mathrm{ppm}), 2.4\left(\mathrm{~s}, 3 \mathrm{H}, \mathrm{CH}_{3}\right), 1.29-$ 1.30 (t, 3H, $\mathrm{CH}_{3} \mathrm{CH}_{2}$ ), 4.37-4.43 (q, 2H, $\mathrm{CH}_{3} \mathrm{CH}_{2}$ ), 4.31-4.32 (m, 3H, CH-CH, CH of oxazolone), 6.9-8.1 (m, 14H, Ar-H, $\mathrm{CH}=\mathrm{C})$.

A mixture of $2(0.005 \mathrm{~mol})$ and ethylacetoacetate $(0.01$ mol) in $30 \mathrm{~mL}$ ethanol was added dropwise to $10 \mathrm{~mL}$ sodium hydroxide $(10 \%)$, the mixture was stirred at room temperature for $24 \mathrm{~h}$, then poured into $5 \mathrm{~mL}$ of $5 \% \mathrm{HCl}$. The formed solid was filtered, washed with water and recrystallized from ethanol to give 21.

2-acetyl-4-benzamido-3-(4-(tosyloxy)phenyl)pentanedioic acid (21). IR (KBr), $v_{\max } / \mathrm{cm}^{-1}: 1670$ (CO, amidic), 1700 (CO), $3400(\mathrm{OH}), 3300(\mathrm{NH}), 1640(\mathrm{C}=\mathrm{N}), 1360\left(\mathrm{SO}_{3}\right)$. EIMS (m/z, \%): $539\left(\mathrm{M}^{+}, 46\right), 457$ (10), 382 (100), 298 (10), 254 (35), 181 (27), 147 (16), 111 (15), 91 (56).

A mixture of compound $2(0.005 \mathrm{~mol})$, the appropriate nitroalkane namely, nitromethane and/or nitroethane $(0.01$ $\mathrm{mol})$ and few drops of triethylamine in ethanol $(30 \mathrm{~mL})$ was refluxed with stirring for $12 \mathrm{~h}$, then poured onto ice-water, The solid that separated was filtered off and recrystallized from ethanol to give $\mathbf{2 2}$ and $\mathbf{2 3}$, respectively.

4-(2-Nitro-1-(5-oxo-2-phenyl-4,5-dihydrooxazol-4-yl)ethyl)phenyl-4-methyl benzene sulfonate (22). IR (KBr), $v_{\max } / \mathrm{cm}^{-1}: 1770(\mathrm{CO}$, lactone $), 1350\left(\mathrm{NO}_{2}\right), 1640(\mathrm{C}=\mathrm{N}), 1360$ $\left(\mathrm{SO}_{3}\right)$. EIMS (m/z, \%): $482(\mathrm{M}+2,19), 411$ (28), 344 (36), 218 (55), 275 (100), 197 (45), 155 (47), 129 (46), 91 (67).

4-(2-Nitro-1-(5-oxo-2-phenyl-4,5-dihydrooxazol-4-yl)propyl)phenyl-4-methyl benzene sulfonate (23). IR (KBr), $v_{\max } / \mathrm{cm}^{-1}: 1770$ (CO, lactone), $1350\left(\mathrm{NO}_{2}\right), 1640(\mathrm{C}=\mathrm{N}), 1360$ $\left(\mathrm{SO}_{3}\right)$. EIMS (m/z, \%): $495\left(\mathrm{M}^{+}, 23\right), 455$ (16), 419 (80), 384 (46), 350 (63), 334 (12), 295 (60), 238 (100), 155 (36). ${ }^{1} \mathrm{H}$ NMR (DMSO) $(\delta, \mathrm{ppm}), 2.4\left(\mathrm{~s}, 3 \mathrm{H}, \mathrm{CH}_{3}\right), 1.7(\mathrm{~d}, 3 \mathrm{H}$, $\left.\mathrm{CH}_{3}-\mathrm{CH}\right), 3.3$ (t, 1H, CH), 4.31-4.32 (m, 2H, O $\mathrm{O}_{2} \mathrm{NCH}-, \mathrm{CH}$ of oxazolone), 6.9-8.1 (m, 14H, Ar- $\mathrm{H}, \mathrm{CH}=\mathrm{C})$.

\subsection{Evaluation of the prepared compounds as lubricating oil additives}

2.2.1 Evaluation of the prepared compounds as antioxidant additives for the tested lubricating oil

A lubricating sample free from additives, as well as lubricating oil samples containing different concentrations of prepared products, were subjected to severe oxidation with an air rate of $10 \mathrm{~L} \cdot \mathrm{h}^{-1}$ at $155^{\circ} \mathrm{C}$ for $36 \mathrm{~h}$. Samples were taken at regular intervals in 3-36 h of oxidation. The oxidation stability of these samples is expressed in terms of total acid number (TAN) according to (ASTMD-3242) (Figs.1-4) 


\subsubsection{Evaluation of the prepared compounds as corrosion} inhibitor additives for the tested lubricating oil

In order to evaluate the corrosion inhibition of the tested lubricating oil samples containing the prepared compounds, strips of three metals: iron, copper and aluminum with surface area of $1 \mathrm{~cm}^{2}$, were used in this study. Every metal was weighed and immersed in the oxidation system for $36 \mathrm{~h}$ under the previous conditions $\left(155^{\circ} \mathrm{C}\right.$ with air rate of $\left.5 \mathrm{~L} / \mathrm{h}\right)$. Then every metal was cleaned and weighed again. The difference in weight was calculated and the efficiency of the used products as corrosion inhibitors was evaluated by using weight loss technique according to ASTMD-130 (Table 3).

\subsubsection{Effect of concentration}

The effect of concentration of additive, which gave the highest antioxidant efficiency for the tested lubricating oil, was studied in order to find the optimum concentration. In our work, three different concentrations of additive $\mathbf{1 5}$ namely, $0.01,0.05$ and $0.1 \mathrm{~g} \cdot \mathrm{L}^{-1}$, were used (Fig. 5).

\subsubsection{Surface tension of lubricating oil after oxidation}

Surface tension was measured for the lubricating oil with and without additives after $36 \mathrm{~h}$ at $155{ }^{\circ} \mathrm{C}$ with air rate of $10 \mathrm{~L} \cdot \mathrm{h}^{-1}$ in order to determine the detergency effect of the additives on oil, by using surface tension apparatus (Torsion Balance White Elec. Co Ltd. No 0/17604f) (Table 4).

\subsubsection{Thermal stability of prepared antioxidant additives}

In order to study the stability of effective antioxidant and anticorrosive additives towards heating, thermal analysis using thermogravimetric analysis (TGA) and differential thermal gravimetric analysis (DTGA) techniques were conducted by using Shimadzu TGA apparatus.

2.2.6 A comparison of the oxidation stability between lubricating oil containing the prepared products and lubricating oil containing a commercial additive

The oxidation stability was compared between the lubricating oil containing the highly efficient prepared antioxidants $\left(0.1 \mathrm{~g} \cdot \mathrm{L}^{-1}\right)$ and the lubricating oil containing a commercial antioxidant additive purchased from the local market (CO-OP Cosf/cc $21 \mathrm{w} / 51$ oil). The results obtained after $36 \mathrm{~h}$ oxidation at $155^{\circ} \mathrm{C}$ with air rate of $10 \mathrm{~L} \cdot \mathrm{h}^{-1}$ (Fig. 6).

\section{Results and discussion}

\subsection{Chemistry}

Many types of organic heterocyclic compounds have been used as antioxidant and anticorrosive additives for lubricating oils. In continuation of our previous studies in the field of antioxidant and anticorrosive additives (Hassan et al, 2010; 2011a; 2011b; Hassan, 2011; Amer et al, 2011; Habib et al, 2010; Habib et al, in press; Cameron, 1966), new additives 2-23 were prepared and their antioxidant and anticorrosive activities were evaluated for some Egyptian local lubricating oils. Thus, the required $(\mathrm{Z})-4-((5-\mathrm{oxo}-2$-phenyloxazol-4(5H)ylidene)methyl)phenyl-4-methyl benzenesulfonate 2, was prepared by means of the reaction of 4-toluenesulfonyloxy benzaldehyde 1 with hippuric acid and acetic anhydride in the presence of freshly fused sodium acetate according to the method reported in literature (Girges et al, 1989).

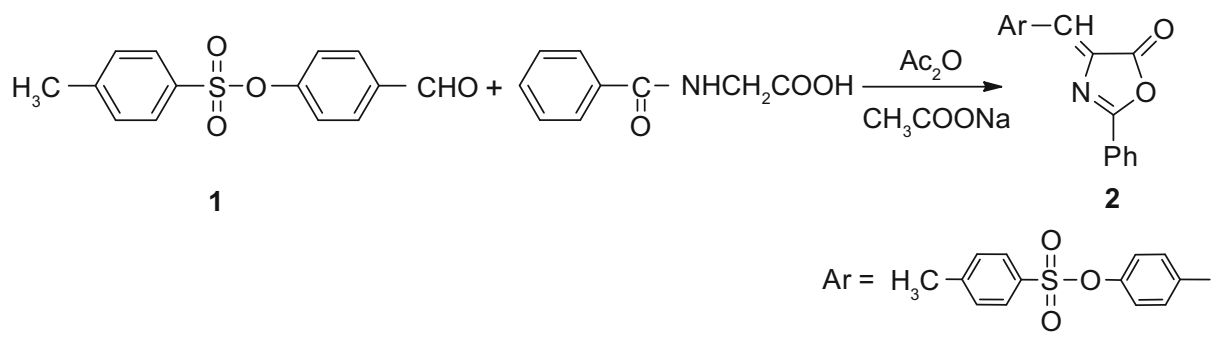

Scheme 1 Synthesis of oxazolone derivative 2

Fusion of oxazolone 2 with $o$-phenylenediamine in the presence of freshly fused sodium acetate at $140{ }^{\circ} \mathrm{C}$ and 190 ${ }^{\circ} \mathrm{C}$ respectively gives different products. When fusion was carried out at $140{ }^{\circ} \mathrm{C}$, compound 3 was obtained, while fusion at $190{ }^{\circ} \mathrm{C}$ leads to the formation of compound 4 . Moreover, reaction of oxazolone 2 with $o$-phenylenediamine in absolute ethanol under reflux afforded compound 5. Furthermore, treatment of oxazolone $\mathbf{2}$ with $o$-phenylenediamine in glacial acetic acid under reflux in the presence of fused sodium acetate gives imidazolone derivative 6 (Table 1) (Scheme 2).

On the other hand, refluxing of one mole of oxazolone 2 with one mole of $p$-phenylenediamine in the presence of glacial acetic acid and fused sodium acetate afforded imidazolone 7, but using two moles of compound 2 to one mole of the other give bis imidazolone 8 (Table 1) (Scheme 3).

In the present investigation, oxazolone 2 reacted with some heterocyclic amines, namely 2 -aminopyridine, 3 -aminopyridine, 2 -aminothiazole, 2 -aminobenzothiazole, 4-aminoantipyrine or 5-amino-4-phenylazo-2,4dihydropyrazol-3-one, in glacial acetic acid and fused sodium acetate giving imidazolone derivatives 9-14 (Table 1) (Scheme 4), respectively.

Cyclocondensation of thiosemicarbazide with oxazolone 2 in dry pyridine afforded (Z)-4-((5-phenyl-2-thioxo- $2 \mathrm{H}$ imidazo[1,5-b][1,2,4]triazol-(3H)-ylidene)methyl)phenyl-4methylbenzene sulfonate 15 (Table 1) (Scheme 5).

The reactivity of the exocyclic $(\mathrm{C}=\mathrm{C})$ bond in the four position of the oxazolone ring is due to conjugation with the adjacent carbonyl group (Habib et al, 1989). In the present work, the addition of piperidine, morpholine, piperazine or thiophenol to the olefinic double bond in the four position of compound 2 gives the corresponding addition products 16-19 (Table 1) (Scheme 6), respectively.

The present investigation deals also with the Michael addition on the exocyclic double bond in compound 2 . Thus addition of ethylcyanoacetate to compound $\mathbf{2}$ in chloroform afforded oxazolone derivative $\mathbf{2 0}$, but the addition of ethylacetoacetate in the presence of sodium hydroxide afforded compound 21. On the other hand, addition of nitromethane and nitroethane to oxazolone 2 leads to the formation of compounds 22 and $\mathbf{2 3}$ (Table 1)(Scheme 7), respectively. 


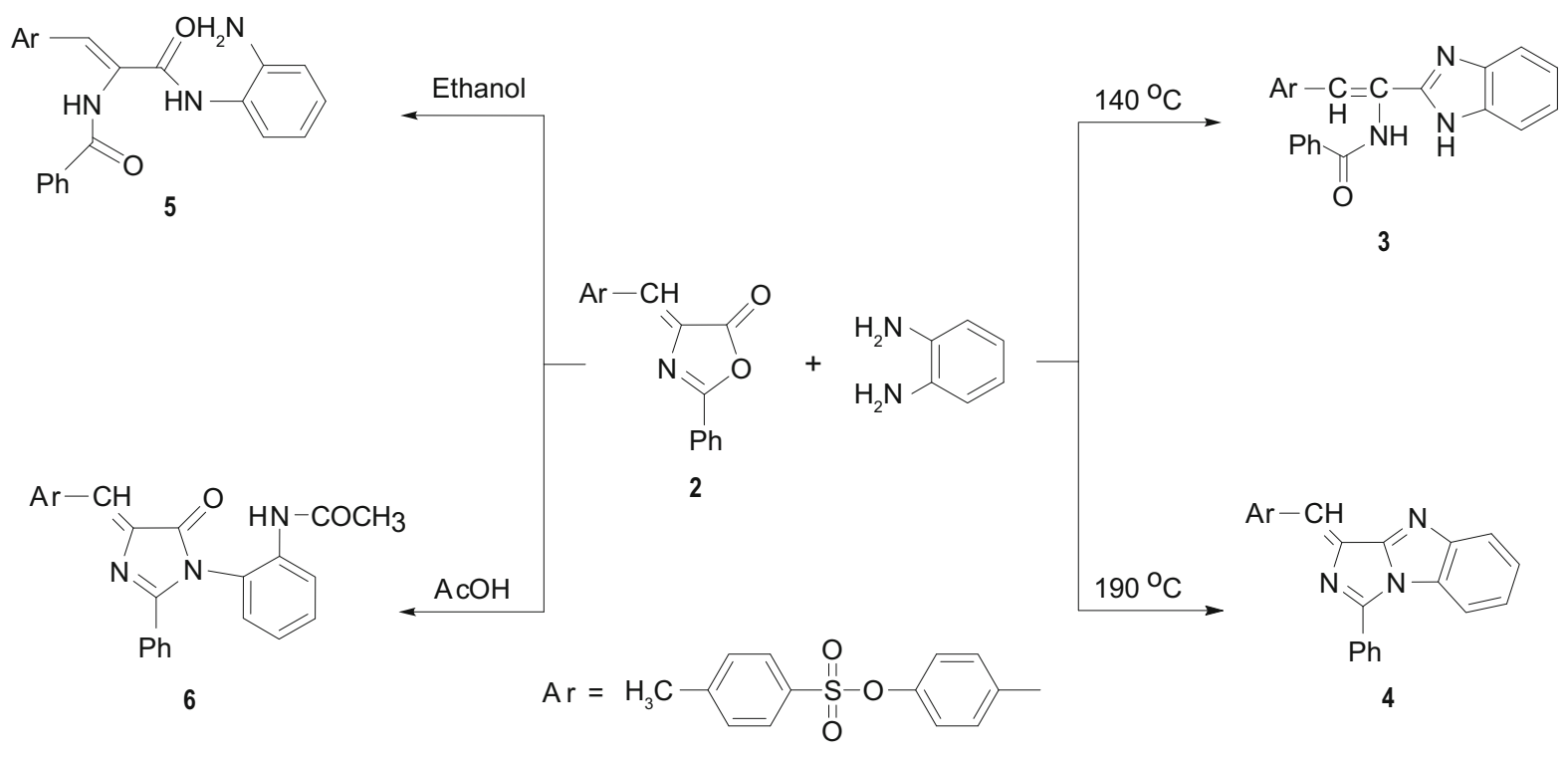

Scheme 2 Reaction of oxazolone 2 with o-phenylenediamine under different conditions

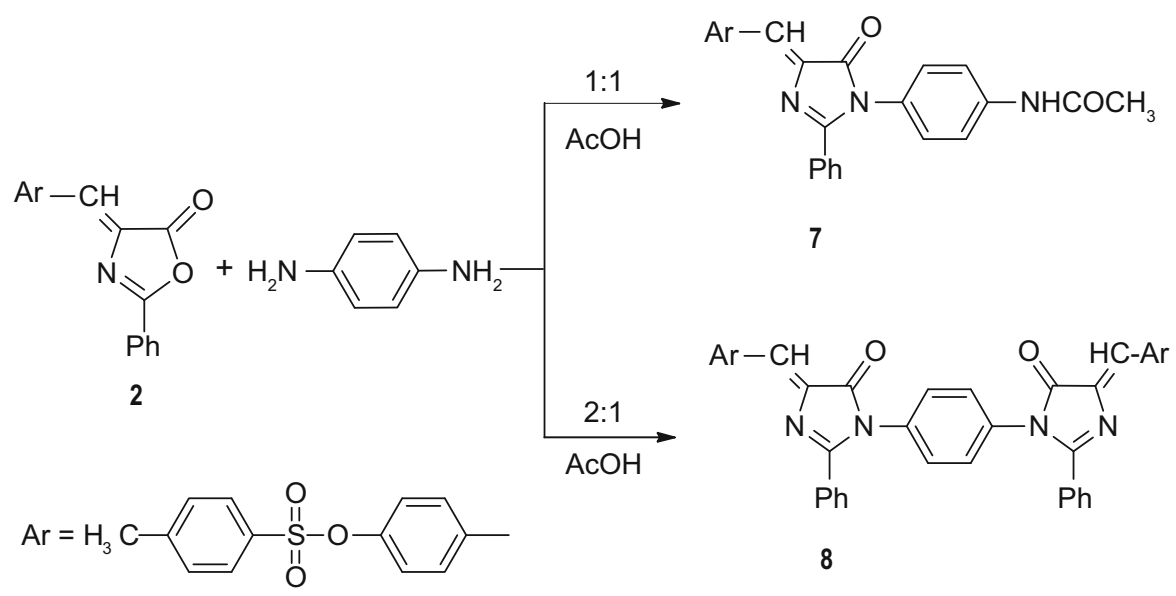

Scheme 3 Reaction of oxazolone $\mathbf{2}$ with p-phenylenediamine under different moles<smiles>O=C1C(=CBr)N=C(c2ccccc2)N1c1nc2ccccc2s1</smiles>

12<smiles>Cc1c(N2C(=O)C(=C[Hg])N=C2c2ccccc2)c(=O)n(-c2ccccc2)n1C</smiles>

13<smiles>O=C1NN=C(N2C(=O)C(=CBr)N=C2c2ccccc2)C1N=P</smiles>
14<smiles>CCC(=O)O</smiles><smiles></smiles>
$\mathrm{Ar}-\mathrm{CH}$

2<smiles>NC1=NNC(=O)C1/N=N\c1ccccc1</smiles>

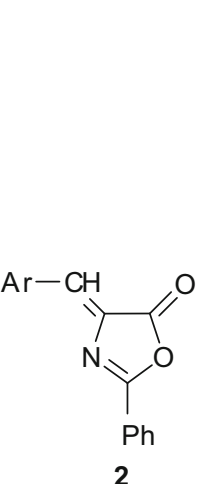

$\underset{\mathrm{N}-}{\longrightarrow}$<smiles>O=C1C(=C[Hg])N=C(c2ccccc2)N1c1ccccn1</smiles>

9

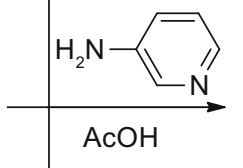<smiles>O=C1C(=C[Al])N=C(c2ccccc2)N1c1cccnc1</smiles>

10<smiles>O=C1C(=C[Al])N=C(c2ccccc2)N1c1nccs1</smiles> 
Table 1 Characterization data of newly prepared compounds

\begin{tabular}{|c|c|c|c|c|c|c|}
\hline \multirow{2}{*}{ Cpd. No. } & \multirow{2}{*}{ m.p. $\left({ }^{\circ} \mathrm{C}\right)$} & \multirow{2}{*}{ Yield (\%), Color } & \multirow{2}{*}{ Mol. Formula (wt) } & \multicolumn{3}{|c|}{$\begin{array}{c}\text { Elemental analysis } \\
\text { Calc. (Found) }\end{array}$} \\
\hline & & & & $\mathrm{C} \%$ & $\mathrm{H} \%$ & $\mathrm{~N} \%$ \\
\hline 3 & $149-151$ & 53, Gray powder & $\mathrm{C}_{29} \mathrm{H}_{23} \mathrm{~N}_{3} \mathrm{O}_{4} \mathrm{~S}(509.5)$ & $\begin{array}{c}68.35 \\
(68.31)\end{array}$ & $\begin{array}{c}4.55 \\
(4.50)\end{array}$ & $\begin{array}{c}8.25 \\
(8.15) \\
\end{array}$ \\
\hline 4 & $238-240$ & 63 , Brown powder & $\mathrm{C}_{29} \mathrm{H}_{21} \mathrm{~N}_{3} \mathrm{O}_{3} \mathrm{~S}(491.5)$ & $\begin{array}{c}70.86 \\
(70.81) \\
\end{array}$ & $\begin{array}{c}4.31 \\
(4.30)\end{array}$ & $\begin{array}{r}8.55 \\
(8.45) \\
\end{array}$ \\
\hline 5 & $218-220$ & 65, Grey powder & $\mathrm{C}_{29} \mathrm{H}_{25} \mathrm{~N}_{3} \mathrm{O}_{5} \mathrm{~S}(527.5)$ & $\begin{array}{c}66.02 \\
(66.01)\end{array}$ & $\begin{array}{c}4.78 \\
(4.80)\end{array}$ & $\begin{array}{c}7.96 \\
(7.86) \\
\end{array}$ \\
\hline 6 & $180-182$ & 65 , Yellow powder & $\mathrm{C}_{31} \mathrm{H}_{25} \mathrm{~N}_{3} \mathrm{O}_{5} \mathrm{~S}(551.6)$ & $\begin{array}{c}67.5 \\
(67.4) \\
\end{array}$ & $\begin{array}{c}4.57 \\
(4.50) \\
\end{array}$ & $\begin{array}{c}7.62 \\
(7.65) \\
\end{array}$ \\
\hline 7 & $225-227$ & 80, Yellow powder & $\mathrm{C}_{31} \mathrm{H}_{25} \mathrm{~N}_{3} \mathrm{O}_{5} \mathrm{~S}(551.6)$ & $\begin{array}{c}67.5 \\
(67.1) \\
\end{array}$ & $\begin{array}{c}4.57 \\
(4.49) \\
\end{array}$ & $\begin{array}{c}7.61 \\
(7.62) \\
\end{array}$ \\
\hline 8 & $271-273$ & 75 , Grey powder & $\mathrm{C}_{52} \mathrm{H}_{38} \mathrm{~N}_{4} \mathrm{O}_{8} \mathrm{~S}_{2}(911)$ & $\begin{array}{c}68.56 \\
(68.48) \\
\end{array}$ & $\begin{array}{c}4.2 \\
(4.1)\end{array}$ & $\begin{array}{c}6.15 \\
(6.11) \\
\end{array}$ \\
\hline 9 & $158-160$ & 62, Yellow crystals & $\mathrm{C}_{28} \mathrm{H}_{21} \mathrm{~N}_{3} \mathrm{O}_{4} \mathrm{~S}(495.5)$ & $\begin{array}{c}67.86 \\
(67.81) \\
\end{array}$ & $\begin{array}{c}4.27 \\
(4.20) \\
\end{array}$ & $\begin{array}{c}8.48 \\
(8.35) \\
\end{array}$ \\
\hline 10 & $166-168$ & 72, Yellow powder & $\mathrm{C}_{28} \mathrm{H}_{21} \mathrm{~N}_{3} \mathrm{O}_{4} \mathrm{~S}(495.5)$ & $\begin{array}{c}67.86 \\
(67.78) \\
\end{array}$ & $\begin{array}{c}4.27 \\
(4.25)\end{array}$ & $\begin{array}{c}8.48 \\
(8.49) \\
\end{array}$ \\
\hline 11 & $181-183$ & 52, Yellow crystals & $\mathrm{C}_{26} \mathrm{H}_{19} \mathrm{~N}_{3} \mathrm{O}_{4} \mathrm{~S}_{2}(501.5)$ & $\begin{array}{c}62.26 \\
(62.28)\end{array}$ & $\begin{array}{c}3.82 \\
(3.80)\end{array}$ & $\begin{array}{c}8.38 \\
(8.28)\end{array}$ \\
\hline 12 & $163-165$ & 60, Grey powder & $\mathrm{C}_{30} \mathrm{H}_{21} \mathrm{~N}_{3} \mathrm{O}_{4} \mathrm{~S}_{2}(551.6)$ & $\begin{array}{c}65.32 \\
(65.28) \\
\end{array}$ & $\begin{array}{c}3.84 \\
(3.80) \\
\end{array}$ & $\begin{array}{c}7.62 \\
(7.55) \\
\end{array}$ \\
\hline 13 & 194-196 & 42 , Yellow crystals & $\mathrm{C}_{34} \mathrm{H}_{28} \mathrm{~N}_{4} \mathrm{O}_{5} \mathrm{~S}(604.6)$ & $\begin{array}{c}67.53 \\
(67.58) \\
\end{array}$ & $\begin{array}{c}4.67 \\
(4.60) \\
\end{array}$ & $\begin{array}{c}9.27 \\
(9.24) \\
\end{array}$ \\
\hline 14 & $172-174$ & 46, Yellow powder & $\mathrm{C}_{32} \mathrm{H}_{24} \mathrm{~N}_{6} \mathrm{O}_{5} \mathrm{~S}(604.6)$ & $\begin{array}{r}63.57 \\
(63.58) \\
\end{array}$ & $\begin{array}{c}4.0 \\
(3.80) \\
\end{array}$ & $\begin{array}{r}13.90 \\
(13.88) \\
\end{array}$ \\
\hline 15 & $181-183$ & 41, Grey powder & $\mathrm{C}_{24} \mathrm{H}_{18} \mathrm{~N}_{4} \mathrm{O}_{3} \mathrm{~S}_{2}(474.5)$ & $\begin{array}{c}60.74 \\
(60.71) \\
\end{array}$ & $\begin{array}{r}3.82 \\
(3.79) \\
\end{array}$ & $\begin{array}{r}11.81 \\
(11.78) \\
\end{array}$ \\
\hline 16 & $186-188$ & 25, Yellow powder & $\mathrm{C}_{28} \mathrm{H}_{28} \mathrm{~N}_{2} \mathrm{O}_{5} \mathrm{~S}(504.6)$ & $\begin{array}{c}66.65 \\
(66.55)\end{array}$ & $\begin{array}{c}5.59 \\
(5.55)\end{array}$ & $\begin{array}{c}5.55 \\
(5.54)\end{array}$ \\
\hline 17 & $160-162$ & 31, Yellow crystals & $\mathrm{C}_{27} \mathrm{H}_{26} \mathrm{~N}_{2} \mathrm{O}_{6} \mathrm{~S}(506.5)$ & $\begin{array}{l}64.02 \\
(64.0) \\
\end{array}$ & $\begin{array}{c}5.17 \\
(5.15) \\
\end{array}$ & $\begin{array}{r}5.53 \\
(5.53) \\
\end{array}$ \\
\hline 18 & $221-223$ & 34, Yellow powder & $\mathrm{C}_{27} \mathrm{H}_{27} \mathrm{~N}_{3} \mathrm{O}_{5} \mathrm{~S}(505.5)$ & $\begin{array}{r}64.14 \\
(64.13) \\
\end{array}$ & $\begin{array}{r}5.38 \\
(5.35) \\
\end{array}$ & $\begin{array}{c}8.31 \\
(8.24) \\
\end{array}$ \\
\hline 19 & $196-198$ & 41, Yellow crystals & $\mathrm{C}_{29} \mathrm{H}_{23} \mathrm{NO}_{5} \mathrm{~S}_{2}(529.6)$ & $\begin{array}{c}65.77 \\
(65.73)\end{array}$ & $\begin{array}{c}4.38 \\
(4.35)\end{array}$ & $\begin{array}{c}2.64 \\
(2.54)\end{array}$ \\
\hline 20 & $297-299$ & 28, Yellow powder & $\mathrm{C}_{28} \mathrm{H}_{24} \mathrm{~N}_{2} \mathrm{O}_{7} \mathrm{~S}(532.5)$ & $\begin{array}{c}63.15 \\
(63.13)\end{array}$ & $\begin{array}{c}4.54 \\
(5.55)\end{array}$ & $\begin{array}{c}5.25 \\
(5.21)\end{array}$ \\
\hline 21 & $285-287$ & 51, White powder & $\mathrm{C}_{27} \mathrm{H}_{25} \mathrm{NO}_{9} \mathrm{~S}(539.5)$ & $\begin{array}{c}60.10 \\
(60.13) \\
\end{array}$ & $\begin{array}{c}4.67 \\
(4.65) \\
\end{array}$ & $\begin{array}{c}2.60 \\
(2.54) \\
\end{array}$ \\
\hline 22 & $205-207$ & 38 , Yellow crystals & $\mathrm{C}_{24} \mathrm{H}_{20} \mathrm{~N}_{2} \mathrm{O}_{7} \mathrm{~S}(480.4)$ & $\begin{array}{c}59.99 \\
(60.03) \\
\end{array}$ & $\begin{array}{r}4.20 \\
(4.25) \\
\end{array}$ & $\begin{array}{c}5.83 \\
(5.84) \\
\end{array}$ \\
\hline 23 & $165-167$ & 25, Yellow powder & $\mathrm{C}_{25} \mathrm{H}_{22} \mathrm{~N}_{2} \mathrm{O}_{7} \mathrm{~S}(494.5)$ & $\begin{array}{c}60.72 \\
(60.73)\end{array}$ & $\begin{array}{c}4.48 \\
(4.45)\end{array}$ & $\begin{array}{c}5.66 \\
(5.56)\end{array}$ \\
\hline
\end{tabular}

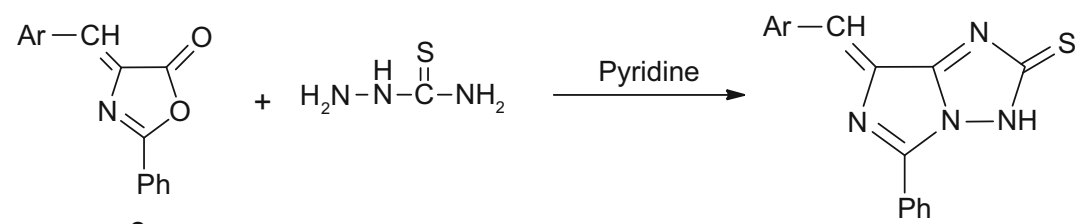

2<smiles>Cc1ccc(OS(=O)(=O)c2ccc(C)cc2)cc1</smiles> 
<smiles>O=C1OC(c2ccccc2)=NC1C([Al])N1CCNCC1</smiles>

18<smiles>O=C1OC(c2ccccc2)=NC1C([Al])Sc1ccccc1</smiles>

19
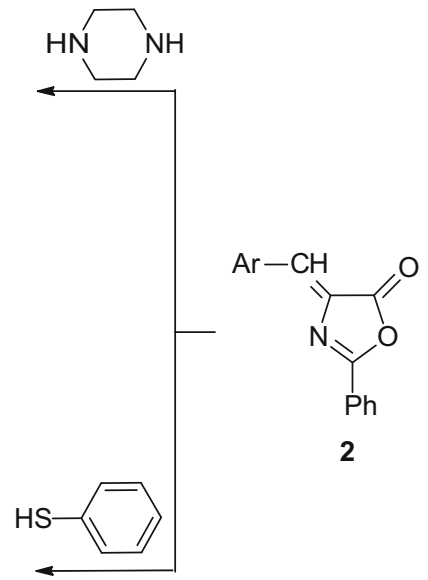

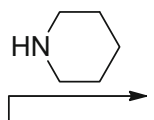<smiles>C1CCNCC1</smiles>

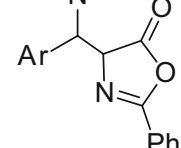

16<smiles>O=C1OC(c2ccccc2)=NC1C(Cl)C1CCOCC1</smiles>

17

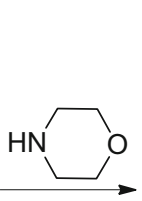

Scheme 6 Reaction of oxazolone 2 with secondary amines and thiophenol<smiles>O=C([O-])C([Al])C1N=C(c2ccccc2)OC1=O</smiles>

22

23
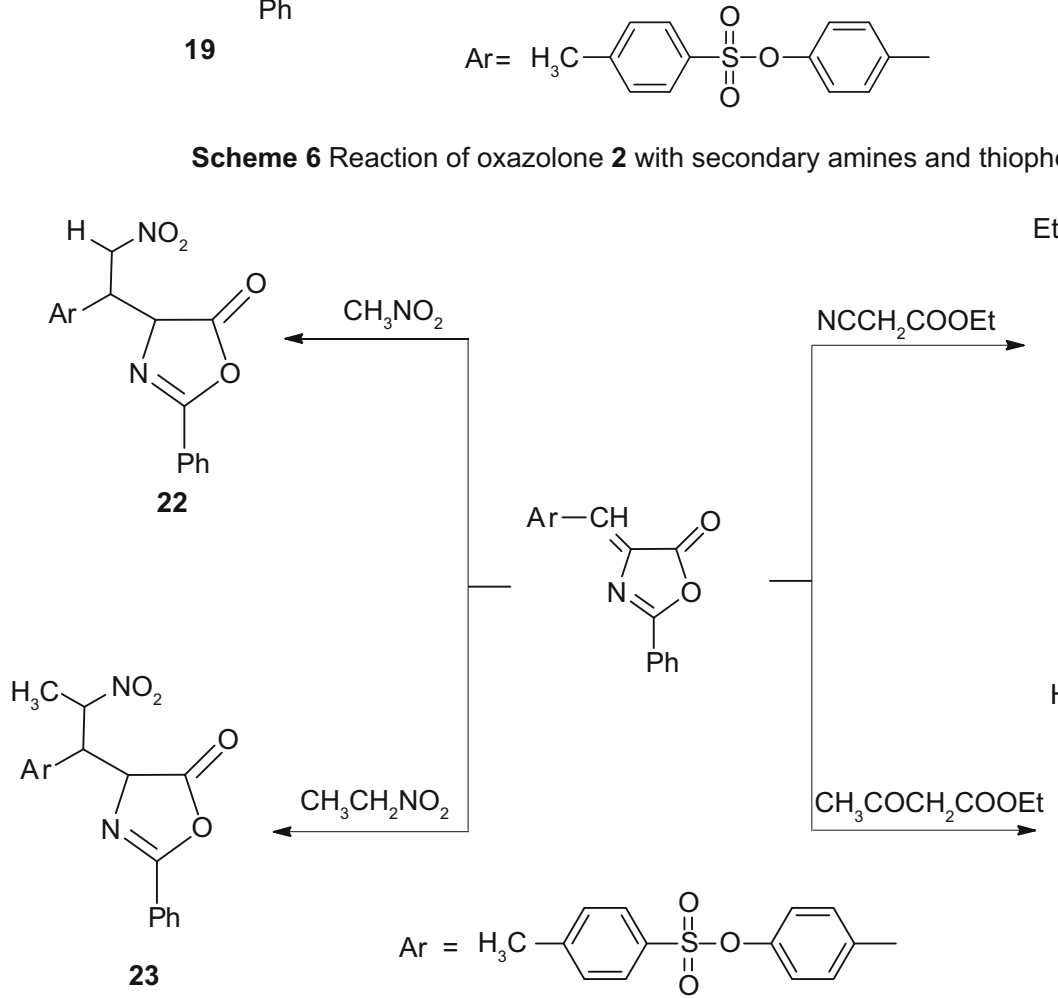<smiles>CCOC(=O)C([Al])C1N=C(c2ccccc2)OC1=O</smiles>

20<smiles>CC(=O)C(C(=O)O)C(NC(=O)C(=O)c1ccccc1)C(=O)O</smiles>

21

Scheme 7 Reaction of oxazolone 2 with active methylene compounds

\subsection{Antioxidant and anticorrosive additives}

\subsubsection{Evaluation of the prepared compounds as antioxidant additives for the tested lubricating oil}

As mentioned in the literature survey, air oxidation of aliphatic hydrocarbons proceeds by a series of free radical reactions as shown by the following scheme:

Initiation:

$\mathrm{RH}+\mathrm{O}_{2} \rightarrow \mathrm{R}^{\cdot}+{ }^{\circ} \mathrm{OOH}$

Propagation:

$$
\begin{aligned}
& \mathrm{R}^{\circ}+\mathrm{O}_{2} \rightarrow \mathrm{ROO}^{\circ} \\
& \mathrm{ROO}^{\circ}+\mathrm{RH} \rightarrow \mathrm{ROOH}+\mathrm{R}^{\circ} \\
& \mathrm{ROOH} \rightarrow \mathrm{RO}^{\circ}+{ }^{\circ} \mathrm{OH} \\
& \mathrm{RO}^{\circ}+\mathrm{RH} \rightarrow \mathrm{ROH}+\mathrm{R}^{\circ}
\end{aligned}
$$

Termination:

$$
\begin{aligned}
& \mathrm{RO}^{*}+\mathrm{R}^{*} \rightarrow \mathrm{ROR} \\
& \mathrm{RO}^{*}+\mathrm{RO}^{\circ} \rightarrow \mathrm{ROOR}
\end{aligned}
$$

The principle requirement for the majority of antioxidants is the presence of a labile hydrogen in their chemical structure or the presence of sulphur or phosphorous. It was stated that, the antioxidant molecule reacts with the peroxy radicals which form during oxidation and leads to the formation of inactive products as shown in the following scheme:

$$
\mathrm{ROO}^{*}+\mathrm{AH} \rightarrow \mathrm{ROOAH}
$$

Followed by:

$\mathrm{ROOAH}+\mathrm{ROO} \rightarrow$ inactive product

or:

$\mathrm{ROO}^{*}+\mathrm{AH} \rightarrow \mathrm{ROOH}+\mathrm{A}^{\circ}$ 
$\mathrm{ROO}^{*}+\mathrm{A} \rightarrow$ inactive product

where, $\mathrm{AH}$ is the antioxidant molecule and $\mathrm{A}$ is an antioxidant radical. Thus, as the labile hydrogen atoms increase, the efficiency of the antioxidant effect would also be increased.

To verify the effectiveness of the synthesized compounds as antioxidants, we prepared different solutions by adding $0.1 \mathrm{~g}$ of the selected compound to $1 \mathrm{~L}$ of the additivefree tested lubricating oil, then the lubricating oil with and without additives was subjected to severe oxidation at 155 ${ }^{\circ} \mathrm{C}$ with air at a rate of $10 \mathrm{~L} \cdot \mathrm{h}^{-1}$ for $36 \mathrm{~h}$. Samples were taken at regular intervals of $3 \mathrm{~h}$ for testing their oxidation stability, which is expressed in terms of the total acid number (TAN) according to ASTMD 3242, and recorded their UV spectra and then compared them with the lubricating oil sample free from additives. The results showed that, in the absence of additives, the oxidation products increased with time. When the prepared additives $\mathbf{2 - 2 3}$ were added to the tested lubricating oil at a concentration of $0.1 \mathrm{~g} \cdot \mathrm{L}^{-1}$, the oxidation products increased at a rate much lower than that without additives, as shown in Figs. 1-4 and Table 2. The highest antioxidant activity was observed in the presence of 11-15 compounds due to the presence of some antioxidant groups in each of them. Compound 14, which were the most effective antioxidant additive have many antioxidant moieties, such as imidazolone and pyrazolone moieties, and some antioxidant groups such as $\mathrm{N}=\mathrm{N}$ and $\mathrm{NH}$ groups, while, compound $\mathbf{1 5}$ contains imidazolone and thiotriazole moieties. On the other hand, compounds 11-13 exhibited the highest antioxidant activity because they contain thiazole, benzothiazole, and pyrazole moieties, respectively, beside the imidazolone moiety in each of them.

\subsubsection{Evaluation of the prepared compounds as corrosion inhibitors for the tested lubricating oil}

Once more, the prepared compounds were tested as corrosion inhibitors for the corresponding lubricating oil using three different strips of copper, iron and aluminum with an area of $1 \mathrm{~cm}^{2}$. The results showed a loss in the weight of metal strips for oil without additives. While in the presence of the compounds 2-23, higher corrosion inhibition was

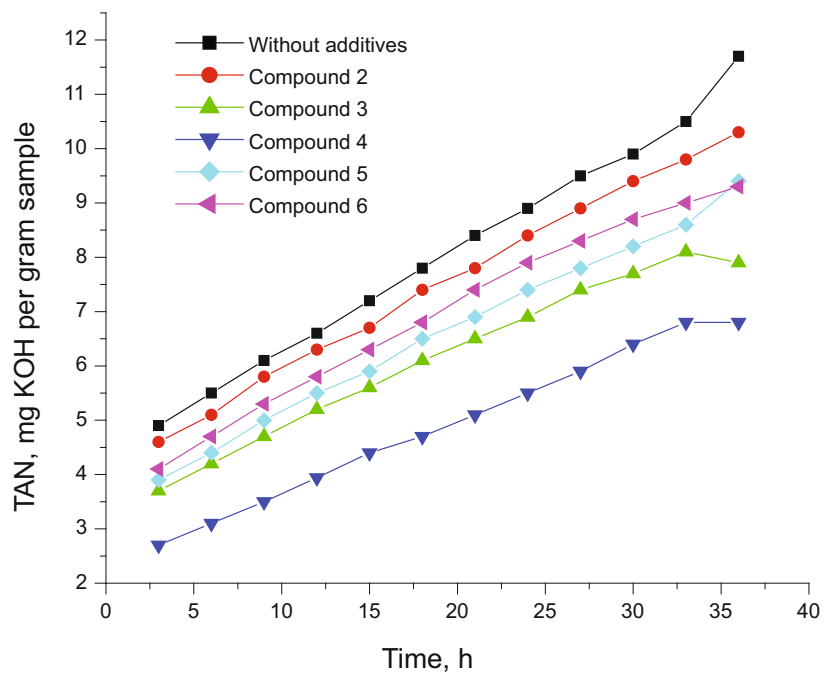

Fig. 1 Variation of total acid number (TAN) with oxidation time of lubricating oil sample without and with additives 2-6 at $0.1 \mathrm{~g} / \mathrm{L}$ concentration at $155^{\circ} \mathrm{C}$ in $3-36 \mathrm{~h}$

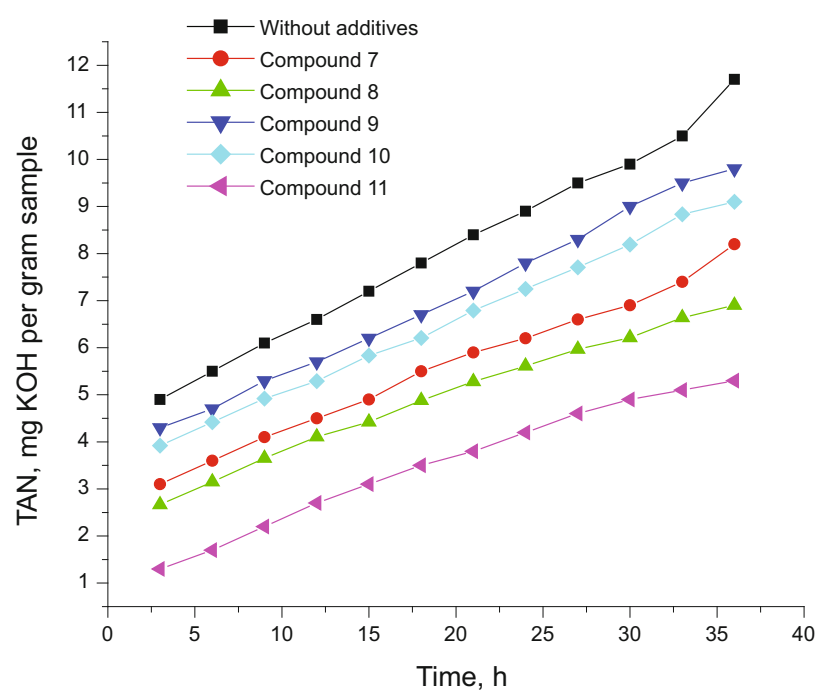

Fig. 2 Variation of the TAN with oxidation time of the lubricating oil sample without and with additives 7-11 at $0.1 \mathrm{~g} / \mathrm{L}$ concentration at $155^{\circ} \mathrm{C}$ in $3-36 \mathrm{~h}$

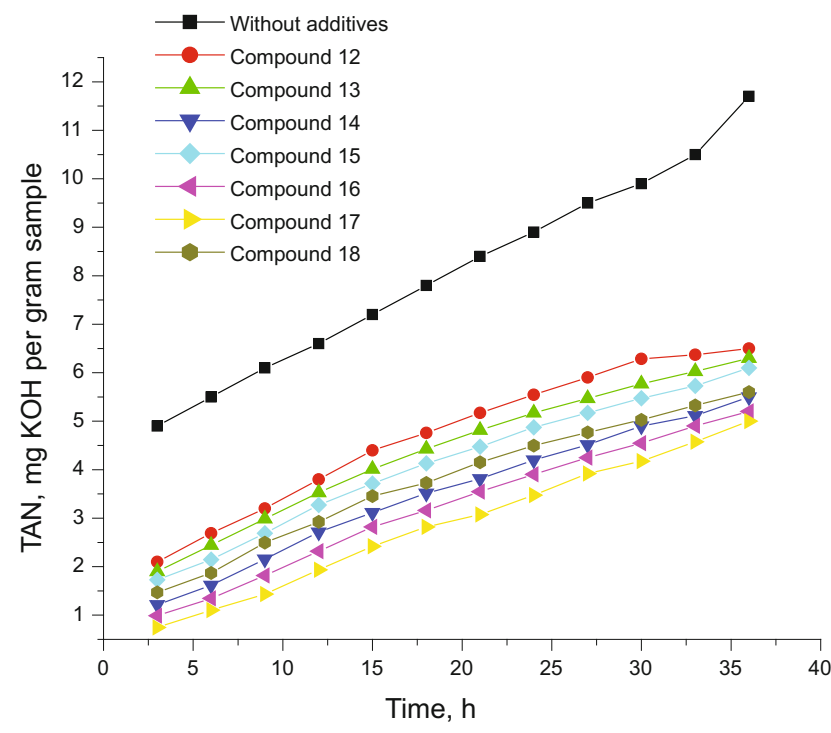

Fig. 3 Variation of the TAN with oxidation time of the used lubricating oil sample without and with additives 12-18 at $0.1 \mathrm{~g} / \mathrm{L}$ concentration at $155^{\circ} \mathrm{C}$ in $3-36 \mathrm{~h}$

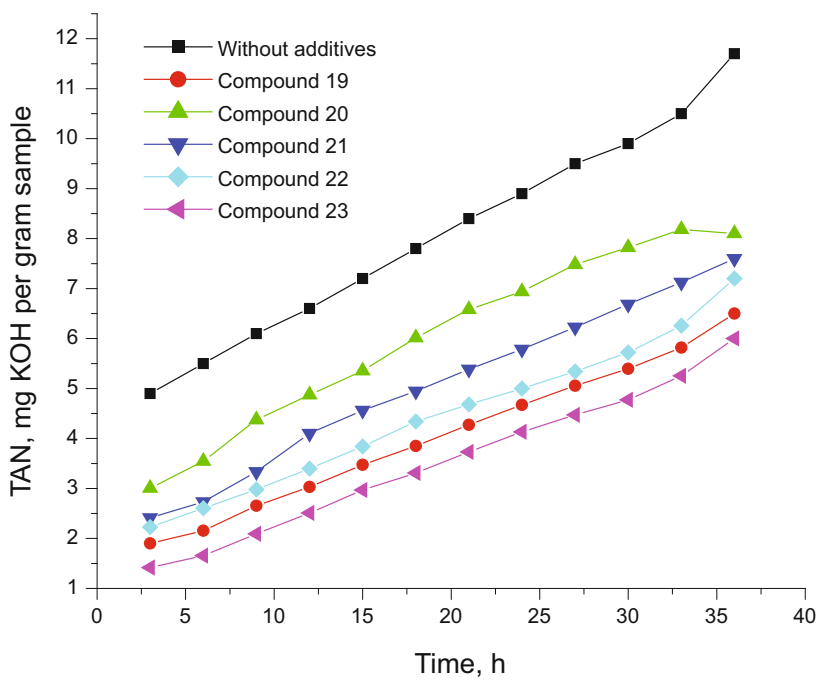

Fig. 4 Variation of the TAN with oxidation time of the lubricating oil sample without and with additives 19-23 at $0.1 \mathrm{~g} / \mathrm{L}$ concentration at $155^{\circ} \mathrm{C}$ in $3-36 \mathrm{~h}$ 
Table 2 Comparison of oxidation stability of lubricating oil in the presence and absence of additives 2-23

\begin{tabular}{|c|c|c|c|c|c|}
\hline Compound No. & $\begin{array}{l}\text { Acid value } \\
\text { gm } \mathrm{KOH} / \mathrm{g}\end{array}$ & $\begin{array}{l}\text { Peroxide value } \\
\text { gm }(\mathrm{KI}) / \mathrm{g} \text { oil }\end{array}$ & $\begin{array}{c}\text { Carbonyl value } \\
\text { gm }(\mathrm{O}) / \mathrm{g} \text { oil }\end{array}$ & $\begin{array}{c}\text { Ester value } \\
\text { gm }(\mathrm{KOH}) / \mathrm{g} \text { oil }\end{array}$ & $\begin{array}{l}\text { Hydroxyl value } \\
\text { gm }(\mathrm{KOH}) / \mathrm{g} \text { oil }\end{array}$ \\
\hline Without additives & 11.7 & 16.5 & 36.0 & 60.0 & 125.0 \\
\hline With additive 2 & 10.3 & 8.2 & 30.6 & 54.4 & 111.3 \\
\hline 3 & 7.9 & 11.2 & 25.6 & 41.5 & 63.6 \\
\hline 4 & 6.8 & 8.9 & 10.9 & 40.3 & 39.5 \\
\hline 5 & 9.4 & 9.5 & 21.2 & 51.3 & 66.7 \\
\hline 6 & 9.3 & 10.5 & 22.8 & 46.7 & 71.5 \\
\hline 7 & 8.2 & 9.9 & 15.4 & 40.5 & 66.8 \\
\hline 8 & 6.9 & 9.8 & 14.4 & 48.4 & 57.8 \\
\hline 9 & 9.8 & 11.2 & 30.2 & 44.6 & 91.5 \\
\hline 10 & 9.1 & 10.1 & 22.2 & 50.6 & 86.7 \\
\hline 11 & 5.3 & 13.4 & 18.7 & 34.6 & 74.7 \\
\hline 12 & 5.2 & 7.8 & 12.5 & 49.6 & 66.7 \\
\hline 13 & 5.5 & 12.4 & 28.5 & 50.4 & 75.0 \\
\hline 14 & 5.0 & 10.4 & 27.6 & 44.5 & 85.7 \\
\hline 15 & 5.6 & 10.3 & 15.3 & 44.5 & 92.5 \\
\hline 16 & 6.3 & 6.8 & 10.3 & 45.4 & 37.8 \\
\hline 17 & 6.5 & 7.4 & 9.7 & 40.4 & 46.7 \\
\hline 18 & 6.1 & 6.8 & 7.8 & 33.6 & 39.5 \\
\hline 19 & 7.2 & 9.5 & 30.2 & 41.5 & 71.5 \\
\hline 20 & 6.5 & 10.5 & 22.2 & 40.3 & 66.8 \\
\hline 21 & 6.0 & 9.9 & 18.7 & 51.3 & 57.8 \\
\hline 22 & 8.1 & 9.8 & 12.5 & 46.7 & 91.5 \\
\hline 23 & 7.6 & 11.2 & 28.5 & 40.5 & 86.7 \\
\hline
\end{tabular}

observed, as shown in Table (3).

\subsubsection{Mechanism of corrosion inhibition}

In lubricating oil, compounds $\mathbf{2 - 2 3}$ exist as neutral molecules, in general, the mode of adsorption could be considered. The neutral form may be adsorbed on the metal surface via a chemisorption mechanism, involving the displacement of oil molecules from the metal surface and the sharing electrons between the N, O and S atoms and metal. In addition, lone-pair electrons of $\mathrm{N}$ and $\mathrm{O}$ atoms in the investigated compounds 2-23 may combine with freshly generated $\mathrm{M}^{2+}$ or $\mathrm{M}^{3+}$ ions on metal surface, forming metal inhibitor complexes.

$$
\begin{aligned}
& \mathrm{M} \rightarrow \mathrm{M}^{2+} \quad+\quad 2 \mathrm{e} \\
& \text { Inh. }+\mathrm{M}^{2+} \leftrightarrow[\text { Inh.-M }]^{2+} \\
& {[\text { Inh. }] \mathrm{n}^{+}+\mathrm{M}^{2+} \leftrightarrow\left[\operatorname{Inh}_{\cdot \mathrm{n}}-\mathrm{M}\right]^{(2+\mathrm{n})+}} \\
& \mathrm{M}=\mathrm{Fe} \text { and } \mathrm{Cu}
\end{aligned}
$$

In case of aluminum as metal the equations will be as follows:

$$
\begin{aligned}
& \mathrm{Al} \rightarrow \mathrm{Al}^{3+} \quad+\quad 3 \mathrm{e} \\
& \text { Inh. }+\mathrm{Al}^{3+} \leftrightarrow[\text { Inh.- } \mathrm{Al}]^{3+}
\end{aligned}
$$

$[\operatorname{Inh}.] \mathrm{n}^{+}+\mathrm{Al}^{3+} \leftrightarrow\left[\operatorname{Inh}_{\cdot \mathrm{n}}-\mathrm{Al}\right]^{(3+\mathrm{n})+}$

These complexes might be adsorbed onto the metal surface by van der Waal's forces to form protective films. On the other hand, the surface coordination is through the nitrogen atoms. It can be concluded that the mode of adsorption depends on the affinity of the metal towards the $\pi$-electron clouds of the ring system. Metals such as $\mathrm{Cu}$ and $\mathrm{Fe}$, which have a greater affinity towards aromatic moieties, were found to adsorb benzene rings in a flat orientation. Thus, it is reasonable to assume that the tested inhibitors are adsorbed in a flat orientation through the $\mathrm{N}$ - and $\mathrm{O}$-atoms. It was found that, the prepared compounds (2-23) showed good corrosion inhibition for all the metals used. This could be explained by the presence of heterocyclic moieties in their structures. Also, in the presence of $\mathrm{NH}, \mathrm{C}=\mathrm{N}$ groups and sulfur atom which may react with these metals to form the corresponding sulphides.

\subsubsection{Effect of concentration}

For the compound that gave the highest antioxidant efficiency, the effect of its concentration was investigated to find the optimum concentration recommended to be used. Thus, three different concentrations of additive 15, namely $0.01,0.05$ and $0.1 \mathrm{~g}$, for $1 \mathrm{~L}$ lubricating oil were used. 
Table 3 Effect of additive types at $0.1 \mathrm{~g} / \mathrm{L}$ concentration in the oil on the weight loss of metals (iron, copper, and aluminum) after $36 \mathrm{~h}$ oxidation at $155^{\circ} \mathrm{C}$ with air rate of $5 \mathrm{~L} / \mathrm{h}$

\begin{tabular}{|c|c|c|c|}
\hline \multirow{2}{*}{ Compound No. } & \multicolumn{3}{|c|}{$\begin{array}{l}\text { Weight loss } \\
\left(10^{-3} \mathrm{~g}\right)\end{array}$} \\
\hline & $\mathrm{Cu}$ & $\mathrm{Fe}$ & $\mathrm{Al}$ \\
\hline Without additives & 11.8 & 14.7 & 9.2 \\
\hline With additive 2 & 2.5 & 7.8 & 1.8 \\
\hline 3 & 2.6 & 5.1 & 1.5 \\
\hline 4 & 2.7 & 7.9 & 1.3 \\
\hline 5 & 4.6 & 4.6 & 3.7 \\
\hline 6 & 3.7 & 6.5 & 5.4 \\
\hline 7 & 2.2 & 6.2 & 4.3 \\
\hline 8 & 5.8 & 4.8 & 3.6 \\
\hline 9 & 4.2 & 6.7 & 4.6 \\
\hline 10 & 6.1 & 7.7 & 1.3 \\
\hline 11 & 6.8 & 2.4 & 1.2 \\
\hline 12 & 3.5 & 3.5 & 2.6 \\
\hline 13 & 2.2 & 6.8 & 6.4 \\
\hline 14 & 2.8 & 6.9 & 4.4 \\
\hline 15 & 4.3 & 8.9 & 1.8 \\
\hline 16 & 1.8 & 1.7 & 1.9 \\
\hline 17 & 1.7 & 15.5 & 1.6 \\
\hline 18 & 4.2 & 6.4 & 1.5 \\
\hline 19 & 2.8 & 7.7 & 4.3 \\
\hline 20 & 4.3 & 2.4 & 3.6 \\
\hline 21 & 1.8 & 3.5 & 4.6 \\
\hline 22 & 1.7 & 6.8 & 1.3 \\
\hline 23 & 4.2 & 6.9 & 1.2 \\
\hline
\end{tabular}

The obtained results showed that, increasing the additive concentration led to decrease of oxidative products, indicating that that concentration of $0.1 \mathrm{~g}$ for $1 \mathrm{~L}$ oil is the more effective concentration to be used for additives 15 (Fig. 5).

\subsubsection{Measurement of surface tension of lubricating oil} after oxidation

Surface tension was measured for lubricating oil with and without additives after heating for $36 \mathrm{~h}$ at $155{ }^{\circ} \mathrm{C}$ with air rate of $10 \mathrm{~L} \cdot \mathrm{h}^{-1}$ in order to determine the detergency effect of additives. As shown in Table (4), we can see that, the surface tension decreased for the lubricating oil in the presence of additives after oxidation compared to that of the additive-free oil. This means that, in presence of compounds 2-23, the need of oil for detergency additives are decreased in comparison with other additives.

\subsubsection{Thermal stability of the prepared antioxidant additives}

Some of the highly effective antioxidant additives, namely additives 11-15, were subjected to thermal analysis using TGA and DTGA techniques. The data indicated that, the first

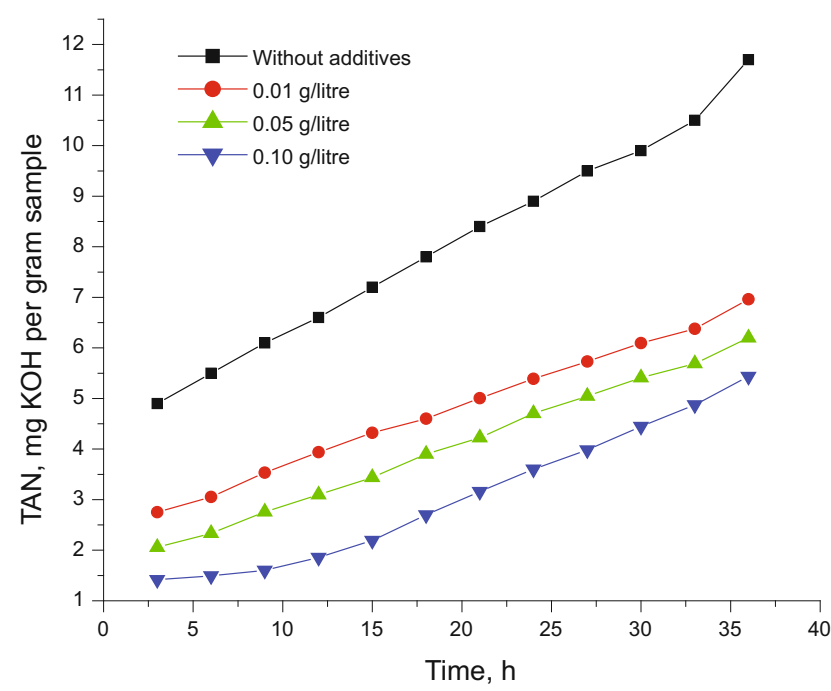

Fig. 5 Variation of the acid value with oxidation time of the lubricating oil samples without or with different concentrations of additive $\mathbf{1 5}$ at $155^{\circ} \mathrm{C}$ in $3-36 \mathrm{~h}$

stage of decomposition began at $185.1{ }^{\circ} \mathrm{C}$ for compound $\mathbf{1 1}$ and at $241.2{ }^{\circ} \mathrm{C}$ for compound $\mathbf{1 2}$, and ended at $251.1^{\circ} \mathrm{C}$ and $272.2{ }^{\circ} \mathrm{C}$ with weight loss of $11.2 \%$ and $16.4 \%$, respectively. Compounds 13-15 began their decomposition in the first stage at $165.5^{\circ} \mathrm{C}, 188.7^{\circ} \mathrm{C}, 199.1{ }^{\circ} \mathrm{C}$, and ended them at $237.5^{\circ} \mathrm{C}$, $245.5^{\circ} \mathrm{C}, 275.3{ }^{\circ} \mathrm{C}$ with weight loss of $11.7 \%, 13.3 \%$ and $10.0 \%$, respectively.

3.2.7 A comparison of the oxidation stability between the tested oil containing the prepared products and lubricating oil containing a commercial additive

The oxidation stability of the tested lubricating oil containing the highly efficient prepared antioxidants $(0.1$ $\left.\mathrm{g} \cdot \mathrm{L}^{-1}\right)$ is compared with that of the lubricating oil containing a commercial antioxidant additive purchased from the local market. The results obtained after $36 \mathrm{~h}$ oxidation at $155^{\circ} \mathrm{C}$ with air rate $10 \mathrm{~L} \mathrm{~h}^{-1}$ are shown in Fig. 6. It can be seen that the lubricating oil containing the compounds 11-15 showed better oxidation stability than the commercial lubricating oil.

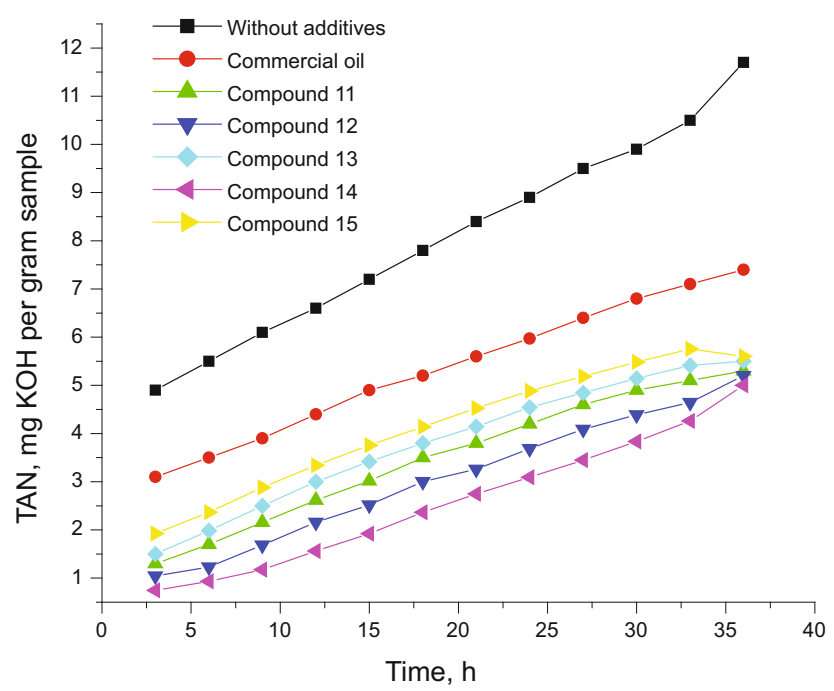

Fig. 6 Evaluation of the tested lubricating oil additives compared with the commercial lubricating oil sample 
Table 4 Surface tension for lubricating oil with and without additives $\left(0.1 \mathrm{~g} \cdot \mathrm{L}^{-1}\right.$ concentration $)$ at $155{ }^{\circ} \mathrm{C}$ after $36 \mathrm{~h}$ of oxidation for additives $\mathbf{2 - 2 3}$

\begin{tabular}{|c|c|c|c|}
\hline Additive used & $\begin{array}{c}\text { Surface tension } \\
\text { dyn } \cdot \mathrm{cm}^{-1}\end{array}$ & Additive used & $\begin{array}{c}\text { Surface tension } \\
\text { dyn } \cdot \mathrm{cm}^{-1}\end{array}$ \\
\hline Lubricating oil before oxidation & 45.0 & Lubricating oil before oxidation & 45.0 \\
\hline Lubricating oil without additives after oxidation & 54.0 & Oil without additives after oxidation & 54.0 \\
\hline Lubricating oil with 2 after oxidation & 42.0 & 13 & 45.0 \\
\hline 3 & 40.0 & 14 & 43.5 \\
\hline 4 & 38.4 & 15 & 40.0 \\
\hline 5 & 37.6 & 16 & 40.0 \\
\hline 6 & 40.0 & 17 & 38.4 \\
\hline 7 & 38.0 & 18 & 37.6 \\
\hline 8 & 41.5 & 19 & 41.5 \\
\hline 9 & 45.0 & 20 & 45.0 \\
\hline 10 & 40.0 & 21 & 43.5 \\
\hline 11 & 38.4 & 22 & 40.0 \\
\hline 12 & 37.6 & 23 & 42.0 \\
\hline
\end{tabular}

\section{Conclusion}

Newly synthesized imidazolone derivatives seem to be interesting for antioxidant and anticorrosive studies. The present investigation offers rapid and effective new procedures for the synthesis of novel imidazolone derivatives incorporating sulfonate moiety. It is clear that incorporation of aryl sulfonate, oxazolone and imidazolone moieties in the same molecule provide high antioxidant and anticorrosive characteristics. On the other hand, incorporation of pyridine, thiazole, benzothiazole and pyrazole rings into imidazolone compounds was crucial for antioxidant and anticorrosive characteristics as in case of compounds 9-14.

\section{References}

Amer F A, Hassan H M, Moawad E B, et al. Synthesis and Evaluation of Some New Thiazoles as Antioxidant Additives for Egyptian Lubricating Oils. Advances in Petroleum Exploration and Development. 2011. 1: 40-49

Aucelio R Q, de Souza R M, de Campos R C, et al. The determination of trace metals in lubricating oils by atomic spectrometry. Spectrochimica Acta part B. 2007. 62: 952-961

Cameron A. The Principles of Lubrication. 1966. London: Longmans

Façanha A, Maria A R, Mazzetto, S E, et al. Evaluation of antioxidant properties of a phosphorated cardanol compound on mineral oils (NH10 and NH20). Fuel. 2007. 86(15): 2416-2421

Girges M M, Abou El-Zahab M M and Hanna M A. Facile synthesis and biological activity of sulfonate ester-containing imidazolylpyridine, imidazo[4,5-b]pyridine and imidazo[5,1:2,3]imidazo[4,5-b]pyridine derivatives. Collect Czech. Chem. Commun.1989. 54: 1096-1103

Habib O M O, Hassan H M, Moawad E B, et al. Evaluation of Some Heterocycles as Antioxidant Additives for Lubricating Oils. Pet. Sci.
\& Tech. 2010. 28: 1059-1067

Habib O M O, Moawad E B and El-Morsy S S. Synthesis of some new heterocyclic conpounds with expected potential biological activity. Journal of Islamic Academy of Sciences.1989. 2: 135-138

Habib O M.O, Hassan H M, Moawad E B, et al. Synthesis of Some Novel Antioxidant and Anticorrosive Additives for Egyptian Lubricating Oils. Pet. Sci. \& Tech. (in press)

Hassan H M, Amer F A, Moawad E B, et al. Synthesis and applications of some new antioxidant and anticorrosive additives for Egyptian diesel motor oils. Lubrication Science. 2010. 22: 163-181

Hassan H M, El-Fedawy M and El-Zimity M T. Synthesis of some antioxidant additives for lubricant oils. Indian J. Technol.1985. 23: 473-475

Hassan H M, Habib O M O, Moawad E B, et al. Synthesis and evaluation of some new multifunction additives for Egyptian gasoline motor oils. Pet. Sci. \& Tech. 2011a. 29: 549-559

Hassan H M, Habib O M O, Moawad E B, et al. Synthesis of some novel antioxidant and anticorrosive additives for Egyptian gasoline motor oils. Lubrication Science. 2011b. 23: 119-138

Hassan H M, Youssif M M, Khalil A M, et al. Synthesis and testing of some new antioxidant and anticorrosion additives with potential for use in turbine aviation oils. J. Synthetic Lubrication. 2000. 17: 55-69

Hassan H M. Utility of Bacterial Biomass as Antioxidant, Anticorrosive and Antifriction Additives for Lubricating Oils. Pet. Sci. \& Tech. 2011. 29: 2086-2094

Hassan H M. Utility of some new multifunctional additives to Egyptian gasoline. Indian J. Technol. 1998. 5: 343-345

Suzuki A, Ulfiati R and Masuko M. Evaluation of antioxidants in rapeseed oils for railway application. Tribology int. 2009. 42: 987994

(Edited by Zhu Xiuqin) 